\title{
Species-specific productivity of Skeletonema costatum (Bacillariophyceae) in the inner part of Tokyo Bay
}

\author{
Myung-Soo Han*, Ken Furuya**, Takahisa Nemoto*** \\ Ocean Research Institute, University of Tokyo, Minamidai, Nakano, Tokyo 164, Japan
}

\begin{abstract}
The composition of red tides in Tokyo Bay varied with season; those during summer 1986 and 1987 were comprised almost entirely of Skeletonema costatum. Primary productivity by S. costatum ranged from 5.2 to $70.4 \%$ of total productivity; on an annual basis, its contribution was $18.8 \%$, as revealed by species-specific photosynthetic rate (SSP), determined by the micromanipulation of ${ }^{14} \mathrm{C}$-labeled cells under simulated in situ conditions. SSP of $S$. costatum normalized with cell volume, an indicator of growth activity, showed temporal variations as the species composition of the red tides changed. The volume-specific SSP was high in the initial phase of the bloom, then decreased gradually with cell division, and reached a minimum at the peak of the bloom. However, the high volume-specific SSP was rather short-lived.
\end{abstract}

\section{INTRODUCTION}

Skeletonema costatum (Greville) Cleve, a cosmopolitan diatom, is distributed widely in coastal and brackish waters and often constitutes a major component of phytoplankton blooms. The importance of $S$. costatum to total primary productivity in coastal areas has been reported from many localities (Hogetsu et al. 1959, Sakshaug \& Andresen 1986, Han 1988). To investigate the mechanism of such blooms and the succession of species, population dynamics have been studied in relation to the physico-chemical conditions (e.g. Smayda 1973, Braarud et al. 1974, Hitchcock \& Smayda 1977). Since inter- and intra-specific variability in photosynthetic or growth rates of phytoplankton can be significant, examination of growth and/or photosynthetic rates of individual species is essential in order to understand the succession. Many attempts have been made in recent years to evaluate cellular and species-specific properties (Rivkin et al. 1982,

\footnotetext{
- Present address: Department of Biology, Hanyang University, Seoul 133-791, Korea

- Present address: Faculty of Bioresources, Mie University, Kamihama, Tsu 514, Japan

*.Professor Nemoto passed away on 22 August 1990
}

Boulding \& Platt 1986, Carpenter \& Chang 1988).

Tokyo Bay, Japan, is a semi-enclosed bay with a narrow central part $6 \mathrm{~km}$ wide restricting the exchange of the bay waters (Fig. 1). Eutrophication in the inner bay has accelerated since the 1960s. Populations of Skeletonema costatum, a dominant alga in Tokyo Bay, have become highly important in phytoplankton dynamics in the inner bay, since they occurred as almost mono-specific red tides or as important members of multi-specific red tides (Marumo \& Murano 1973, Marumo et al. 1974).

The present paper aims to clarify intra- and interspecific variations of photosynthetic rate of Skeletonema costatum and the species' contribution to overall production, and to elucidate the relationship between temporal variations in growth activity of the diatom and its bloom development.

\section{MATERIALS AND METHODS}

Field investigations were carried out at Harumi in the inner bay from May 1986 to June 1987 (Fig. 1). Water samples were taken once or twice a week between May and October 1986 and in May and June 1987. Sampling from November 1986 to April 1987 was biweekly or monthly. Samples were collected at dawn 


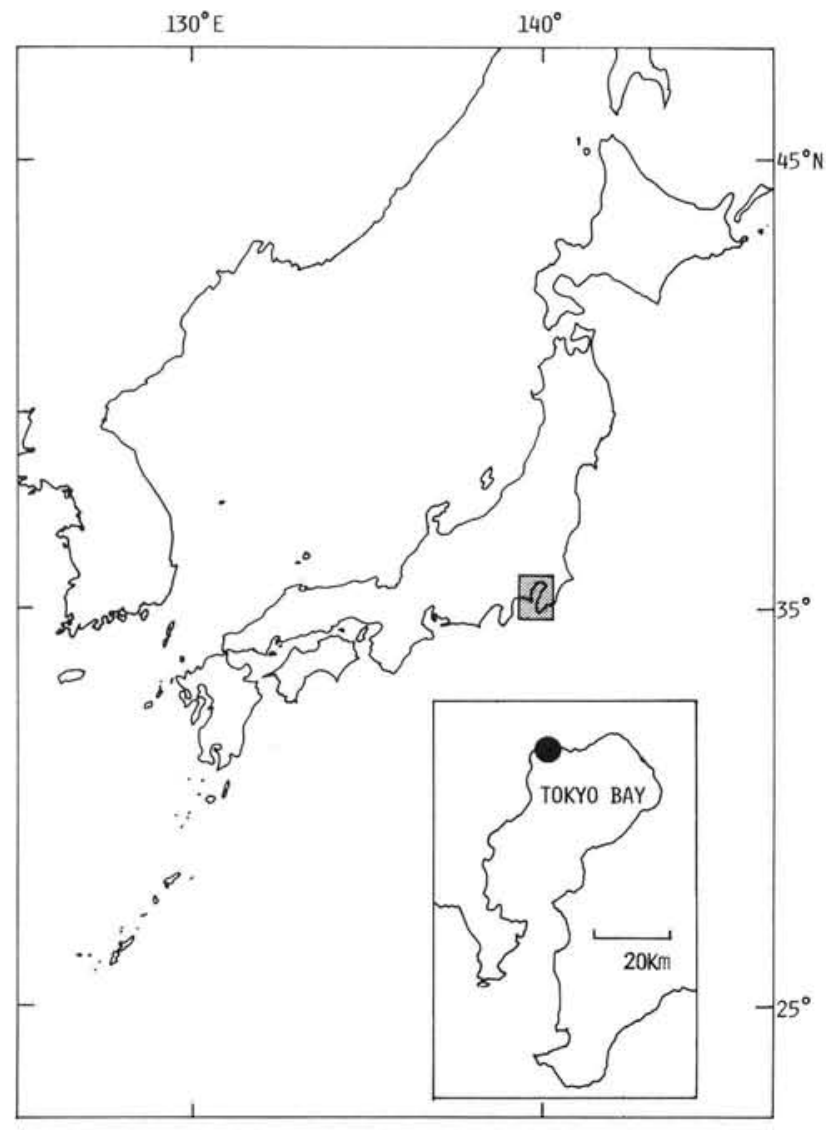

Fig.1. Location of sampling station in Tokyo Bay, Japan

at $0.5 \mathrm{~m}$ depth, where Skeletonema costatum was most abundant. Plankton over $300 \mu \mathrm{m}$ were gently removed by reverse filtration. To facilitate the subsequent isolation procedure, density of cells smaller than $20 \mu \mathrm{m}$ was reduced by reverse filtration through $20 \mu \mathrm{m}$ mesh net. The $>20 \mu \mathrm{m}$ fraction was incubated in a Tefloncoated BOD bottle $(250 \mathrm{ml})$ for 1 to $3 \mathrm{~h}$ with $7.4 \mathrm{MBq}$ $\mathrm{NaH}^{14} \mathrm{CO}_{3}$ (NEN, NEC-086H10) at simulated in situ temperature. Irradiance was 300 to $355 \mu \mathrm{mol} \mathrm{m}^{-2} \mathrm{~s}^{-1}$ of PAR (photosynthetically available radiation) (Biospherical, QSL-100), a saturation intensity as determined by the photosynthesis irradiance (P-I) curve, and thus the photosynthetic rates represent photo- synthetic capacity. Following incubation, each individual cell or chain of $S$. costatum and of other dominant species was picked out at random under a dissecting microscope at a magnification of $\times 100$ and transferred to scintillation vials. Number of cells was counted on picking up a chain. A constant light intensity of 300 to $355 \mu \mathrm{mol} \mathrm{m}^{-2} \mathrm{~s}^{-1}$ was maintained from start of incubation through the single cell isolation under the microscope. The samples of isolated cells were then acidified with 20 to $100 \mu \mathrm{l}$ of $0.5 \mathrm{~N} \mathrm{HCl}$ overnight to purge inorganic ${ }^{14} \mathrm{C}$ and the radioactivity was counted in Aquasol II by a liquid scintillation counter (LKB Wallack Rackbeta 1215). Quench correction was made by the external standard channel ratio method. To determine possible contamination by excreted materials and very small cells, the incubation medium was taken as a blank in the same manner as the cells and transferred to scintillation vials which were assayed for radioactivity in triplicate. All ${ }^{14} \mathrm{C}$ measurements were corrected for background which was negligible when compared to the counts in cells. Carbon uptake for each species was calculated by a regression analysis of activity against number of cells (Fig. 2). The regression was significant throughout the study $(\mathrm{r}>0.99)$. Species-specific photosynthetic rates (SSP) for each species was determined using the slope of this regression line. Primary productivity was calculated from SSP and the numerical abundance in the mixed population. Preliminary investigation showed that when ${ }^{14} \mathrm{C}$-labeled cells were rinsed with a ${ }^{14} \mathrm{C}$-free medium, there was occasional loss of activity, mostly from fragile forms, probably due to leakage of assimilated carbon caused by mechanical damage. Therefore, the rinsing procedure as called for in the original method (Rivkin \& Seliger 1981) was excluded in the present study. Instead, for the correction of possible contamination by labeled dissolved compounds and invisible small organisms in the selected populations, labeled medium without target cells was analyzed in vials serially in the same manner as the isolation. In fact, no significant activity was detected above background levels of 20 to $30 \mathrm{dpm}$ in the blank vials, and a good linear relationship was obtained between the corrected carbon uptake and number of cells (Fig. 2).
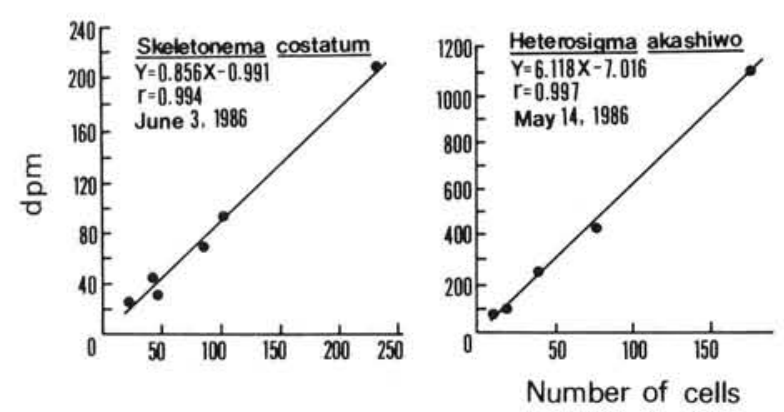

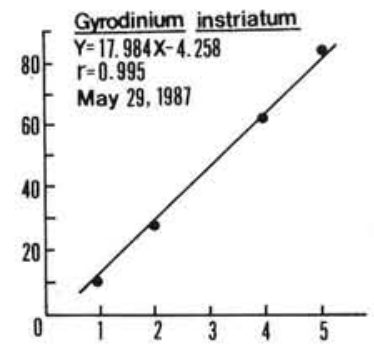

Fig. 2. Examples of ${ }^{14} \mathrm{C}$ uptake as a function of the number of isolated cells per scintillation vial 
Primary production of the total population was determined by the light and dark bottle method in $250 \mathrm{ml}$ Teflon-coated bottles with $\mathrm{NaH}^{14} \mathrm{CO}_{3}$ at $370 \mathrm{KBq}$. After 1 to $2 \mathrm{~h}$ of incubation under the same conditions as described above, phytoplankton was harvested on Whatman GF/F filters under a vacuum pressure of $<250 \mathrm{~mm} \mathrm{Hg}$, and transferred to scintillation vials. After addition of $0.5 \mathrm{~N} \mathrm{HCl}$ to purge unused $\mathrm{NaH}^{14} \mathrm{CO}_{3}$ overnight, activities were assayed as described above. Daily production was calculated using continuous records of solar irradiance as follows: uptake values were taken as instantaneous productivity at incident irradiance equal to or exceeding $160 \mu \mathrm{mol} \mathrm{m} \mathrm{m}^{-2} \mathrm{~s}^{-1}-\mathrm{a}$ mean value of saturation light intensity $(S D=19 \mu \mathrm{mol}$ $\mathrm{m}^{-2} \mathrm{~s}^{-1}$ ) derived from the P-I curves obtained. At lower light intensities, instantaneous productivity was assumed to be linearly proportional to ${ }^{14} \mathrm{C}$ uptake for the light intensity.

Salinity was measured with a salinometer (Guildline, Autosal 8400A). Phosphate, nitrate, nitrite and ammonium were analyzed with an AutoAnalyzer AA-II

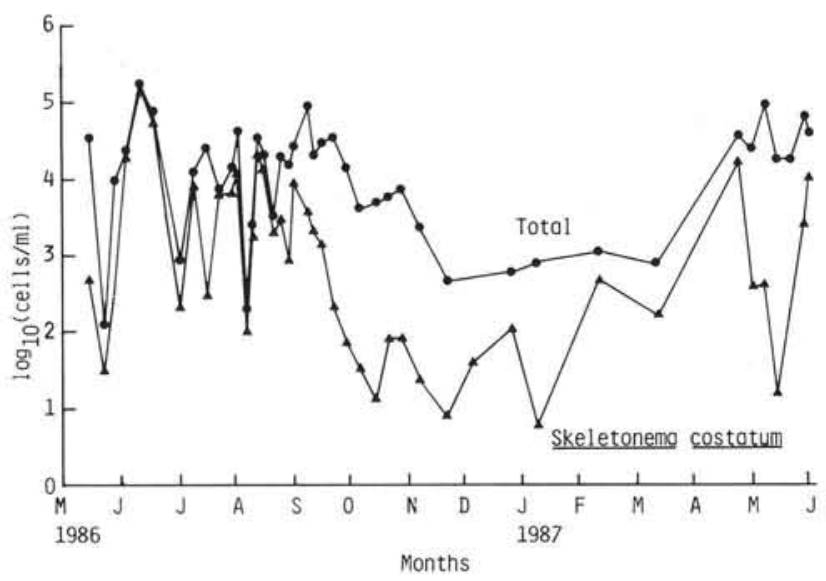

Fig. 3. Seasonal variation in cell numbers of total phytoplankton and Skeletonema costatum

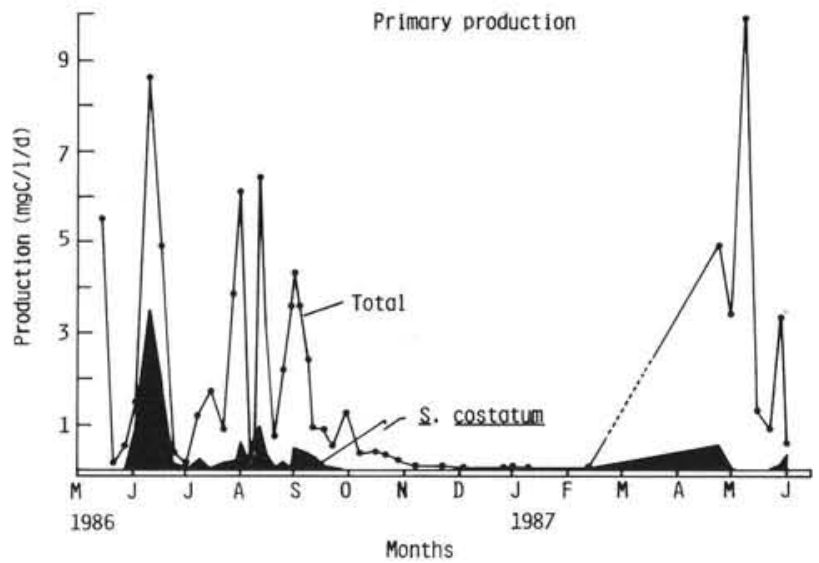

Fig. 4. Seasonal variation in total primary productivity and that of Skeletonema costatum
(Technicon). Total inorganic carbon in sea water was determined by carbonate alkalinity (Parsons et al. 1984) and used for calculation of carbon uptake. Chlorophyll a was fluorometrically measured in a $90 \%$ acetone extract of cells collected on Whatman GF/F filters (Sato et al. 1981). Cell size (average of 30 measurements) was measured under an inverted microscope. The cell volume of each species was calculated from cell shapes and dimensions obtained from microscopic examination of preserved sea water samples (Kovala \& Larrance 1966). Cell organic carbon was calculated by the equations of Strathmann (1967) based on cell volume.

\section{RESULTS}

\section{Numerical abundance}

From late spring through early autumn, Skeletonema costatum was the most dominant species, frequently forming blooms with densities higher than $10^{3}$ cells $\mathrm{ml}^{-1}$ (Fig. 3) and accounting for 28 to $98 \%$ of total cell numbers. The term bloom is used here when total chlorophyll a exceeded $30 \mu \mathrm{g} 1^{-1}$. Heterosigma akashiwo, a raphidophycean, was the next most dominant species in spring and summer. The abundance of the 2 species seemed to be temporally in phase during spring and summer: $H$. akashiwo was low during $S$. costatum blooms and high between the diatom blooms. However, they occasionally occurred together in blooms from late spring to early autumn (Han 1988). From late autumn through early spring, total cell numbers declined significantly and $S$. costatum was only a minor constituent in the phytoplankton community, accounting for less than $20 \%$ of the total.

\section{Productivity}

Total primary production varied widely from 0.04 to $9.91 \mathrm{mg} \mathrm{C}^{-1} \mathrm{~d}^{-1}$ between May 1986 and January 1987 (Fig. 4). Productivity of Skeletonema costatum also fluctuated considerably, from $0.7 \times 10^{-3}$ (14 October 1986) to $3.5 \mathrm{mg} \mathrm{Cl}^{-1} \mathrm{~d}^{-1}$ (10 June 1986), and accounted for 5.2 to $70.4 \%$ of total productivity. On an annual basis $S$. costatum contributed $18.8 \%$. Productivity of $S$. costatum was lowest in winter.

\section{Variation of volume-specific SSP in Skeletonema costatum}

Cell volume and SSP of Skeletonema costatum cells showed considerable seasonal variations. Both tended to be high from November to March and low from May 
to October. Cell volume ranged from 320 to $2840 \mu \mathrm{m}^{3}$ and SSP from 1.84 to $24.07 \mathrm{pgC} \mathrm{h}^{-1}$ cell $^{-1}$ (Fig. 5). The elevation of SSP in winter was due to large cell size. Volume-specific SSP, which was considered an indicator of growth activity, exhibited little dependence on season; e.g. its summer and winter values, when separated arbitrarily by water temperature into groups above and below $17^{\circ} \mathrm{C}$, showed no significant difference ( $p<0.01$, Student's $t$-test). Volume-specific SSP fluctuated between $1.92 \times 10^{-3}(14$ May 1986) and

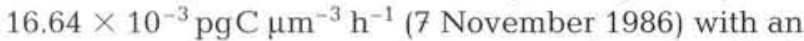

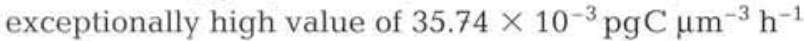
on 6 August 1986 when salinity declined abruptly to $6 \%$ due to heavy rainfall.

Although volume-specific SSP was rather stable on time scales of a season or a year, it showed considerable variations on short time scales: volume-specific SSP of Skeletonema costatum was inversely correlated with blooms (Fig. 6). There was a significant negative relationship between volume-specific SSP and cell numbers $(r=-0.59, p<0.05)$. Volume-specific SSP tended to be higher when population density was lower, and decreased to a minimum around the maximum abundance period. As the bloom progressed towards its peak, volume-specific SSP decreased by a factor of 12 .

Table 1 shows the SSP of dominant species and their relative contribution to total production during bloom and non-bloom periods. Maximum abundance of

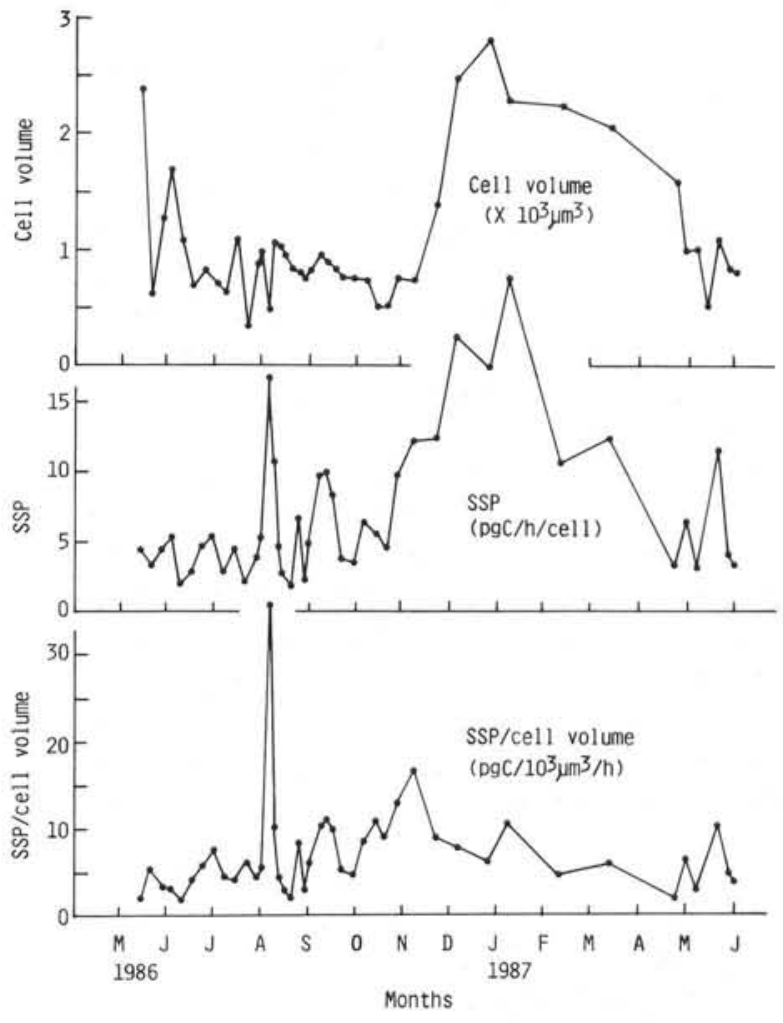

Fig. 5. Skeletonema costatum. Fluctuation of cell volume, species-specific photosynthetic rate (SSP) and SSP/cell volume

Table 1. Biomass and productivity of Skeletonema costatum and co-occurring species during blooming and non-blooming periods

\begin{tabular}{|c|c|c|c|c|c|c|c|c|c|}
\hline $\begin{array}{l}\text { Date } \\
\text { (1986) }\end{array}$ & Species & $\begin{array}{c}\text { SSP } \\
\left(\mathrm{pgC} \mathrm{h}^{-1}\right. \\
\left.\text { cell }^{-1}\right)\end{array}$ & $\begin{array}{l}\text { Cellular } \\
\text { carbon } \\
\text { (pgC) }\end{array}$ & $\begin{array}{c}\text { Growth } \\
\text { rate } \\
\left(\mathrm{h}^{-1}\right)\end{array}$ & $\begin{array}{c}\text { Cell } \\
\text { number } \\
\left(\mathrm{ml}^{-1}\right)\end{array}$ & $\begin{array}{c}\text { Carbon } \\
\text { biomass } \\
\left(\mathrm{mg} \mathrm{C}^{-1}\right)\end{array}$ & $\begin{array}{c}\text { Relative } \\
\text { production } \\
(\%)\end{array}$ & $\begin{array}{c}\text { Total } \\
\text { production } \\
\left(\mu \mathrm{gC} \mathrm{l}^{-1} \mathrm{~h}^{-1}\right)\end{array}$ & $\begin{array}{c}\text { Total } \\
\text { chl } a \\
\left(\mu \mathrm{g} \mathrm{l}^{-1}\right)\end{array}$ \\
\hline \multicolumn{10}{|c|}{ Blooming } \\
\hline $10 \mathrm{Jun}$ & S. costatum & 2.03 & 59.0 & 0.034 & 172615 & 10.18 & 40.7 & 862.3 & 163.8 \\
\hline \multirow[t]{3}{*}{1 Aug } & S. costatum & 5.30 & 69.5 & 0.073 & 10120 & 0.70 & 10.2 & 610.2 & 215.9 \\
\hline & Heterosigma akashiwo & 37.41 & 139.6 & 0.237 & 7520 & 1.05 & 546.1 & 610.2 & 215.9 \\
\hline & Dunaliella sp. & 14.64 & 40.4 & 0.309 & 8084 & 0.33 & 19.4 & 610.2 & 215.9 \\
\hline \multirow[t]{2}{*}{12 Aug } & S. costatum & 4.74 & 73.2 & 0.063 & 20335 & 1.49 & 14.9 & 646.9 & 94.1 \\
\hline & Crichosphaera sp. A & 15.89 & 125.9 & 0.119 & 5514 & 0.69 & 13.6 & 646.9 & 94.1 \\
\hline \multicolumn{10}{|c|}{ Non-blooming } \\
\hline 3 Jun & S. costatum & 5.28 & 100.4 & 0.051 & 19192 & 1.93 & 70.4 & 143.9 & 24.1 \\
\hline \multirow[t]{2}{*}{$22 \mathrm{Jul}$} & S. costatum & 2.05 & 28.8 & 0.069 & 5908 & 0.17 & 14.0 & 86.4 & 16.7 \\
\hline & Eucampia zodiacus & 103.54 & 1186.6 & 0.084 & 390 & 0.46 & 46.8 & 86.4 & 16.7 \\
\hline \multirow[t]{2}{*}{20 Aug } & S. costatum & 1.84 & 61.6 & 0.029 & 1870 & 0.12 & 5.2 & 66.8 & 13.3 \\
\hline & Crichosphaera sp. B & 11.84 & 361.2 & 0.032 & 386 & 0.14 & 10.8 & 66.8 & 13.3 \\
\hline
\end{tabular}


Fig. 6. Skeletonema costatum. Temporal phases of abundance and volume-specific SSP/cell volume

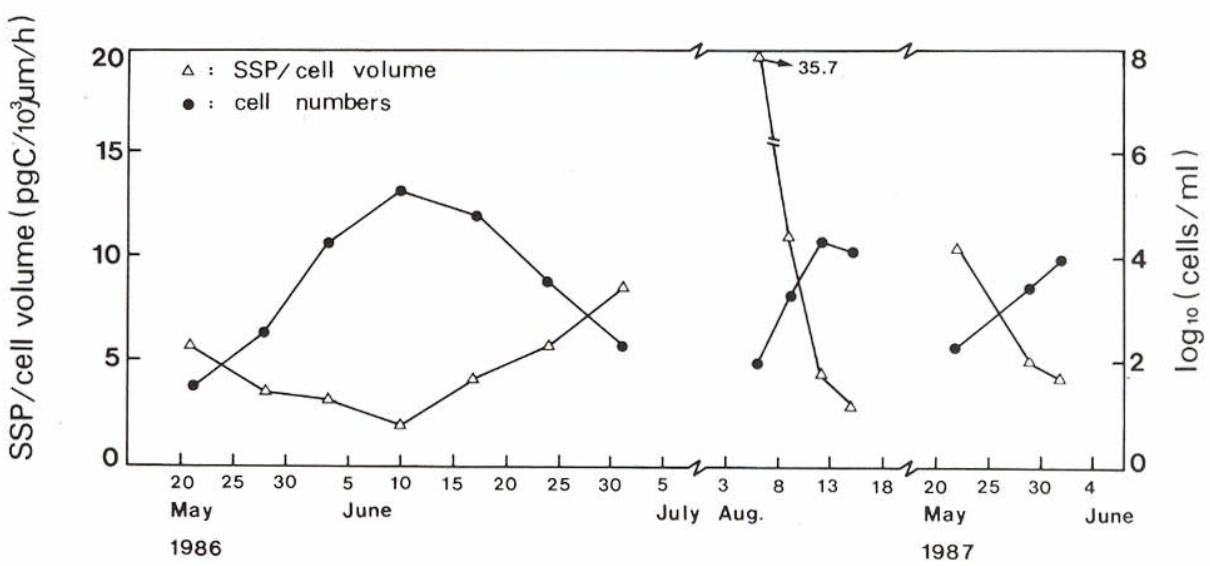

temperature, salinity, nitrate, nitrite, ammonia and phosphate (Fig. 7). Thus, growth of Skeletonema costatum did not appear to be controlled by these factors; nutrients were abundant throughout the year.

\section{Cellular chlorophyll a content}

Chlorophyll a per cell of Skeletonema costatum during the bloom from 24 April to 1 June 1987, was lower than that of Heterosigma akashiwo by one order of magnitude (Table 2). Chlorophyll a per cell volume also showed a similar difference, and the ratio of carbon to chlorophyll a was consistently higher in S. costatum.

\section{DISCUSSION}

The start of Skeletonema costatum blooms always coincided with a high but short-lived volume-specific SSP. Since cell numbers increased following such a
There was no significant relationship between volume-specific SSP and any of following parameters:
Fig. 7. Relationship between temperature, salinity, nitrate, nitrite, ammonia, phosphate and volume-specific SSP (speciesspecific photosynthetic rate) of Skeletonema costatum

Table 2. Skeletonema costatum and Heterosigma akashiwo. Variation in cellular chlorophyll a content and carbon : chl a ratios during a bloom from 24 April to 1 June 1987. Cellular carbon content was converted from cell volume using Strathmann (1967)

\begin{tabular}{|c|c|c|c|c|c|c|c|}
\hline \multirow[b]{2}{*}{$\begin{array}{l}\text { Date } \\
(1987)\end{array}$} & \multirow[b]{2}{*}{$\begin{array}{c}\text { Total } \\
\text { chl a } \\
\left(\mu \mathrm{g} \mathrm{l}^{-1}\right)\end{array}$} & \multicolumn{3}{|c|}{ Skeletonema costatum } & \multicolumn{3}{|c|}{ Heterosigma akashiwo } \\
\hline & & $\begin{array}{c}\text { Chl a } \\
\text { content } \\
\left(\mathrm{pg} \mathrm{cell}^{-1}\right)\end{array}$ & $\begin{array}{l}\text { Chl a: cell vol. } \\
\left(\times 10^{-3} \mathrm{pg} \mu \mathrm{m}^{-3}\right)\end{array}$ & $\begin{array}{l}\mathrm{C}: \mathrm{chl} a \\
\left(\mathrm{pg} \mathrm{pg}^{-1}\right)\end{array}$ & $\begin{array}{c}\text { Chl a } \\
\text { content } \\
\left(\mathrm{pg} \mathrm{cell}^{-1}\right)\end{array}$ & $\begin{array}{l}\text { Chl a:cell vol. } \\
\left(\times 10^{-3} \mathrm{pg} \mu \mathrm{m}^{-3}\right)\end{array}$ & $\begin{array}{l}\text { C:chl a } \\
\left(\mathrm{pg} \mathrm{pg}^{-1}\right)\end{array}$ \\
\hline $24 \mathrm{Apr}$ & 140.5 & - & - & - & 21.97 & 13.48 & 9.6 \\
\hline 1 May & 226.8 & 2.08 & 2.06 & 34.5 & 38.32 & 23.22 & 5.5 \\
\hline 8 & 638.2 & 4.51 & 4.34 & 16.1 & 33.27 & 34.66 & 4.0 \\
\hline 15 & 103.8 & - & - & - & 26.32 & 31.71 & 4.4 \\
\hline 22 & 73.6 & - & - & - & 9.20 & 10.45 & 13.3 \\
\hline 29 & 176.8 & 1.77 & 2.08 & 35.7 & - & - & - \\
\hline 1 Jun & 32.8 & 2.61 & 3.14 & 23.8 & 6.85 & 10.70 & 13.5 \\
\hline
\end{tabular}

period (Fig. 6), the volume-specific SSP may be used as an index of growth potential. No factor was correlated with the variations of volume-specific SSP. However, volume-specific SSP invariably increased with a decline in salinity following rainfall, and then $S$. costatum blooms soon followed. Therefore, a reduced salinity induced by rain was suggested as a trigger of the blooms (Han et al. 1989). Reported values of optimum salinity for $S$. costatum range from 12 to $29 \%$ (Curl \& McLeod 1961, Nishizima \& Hata 1986), although it is able to adapt to salinity as low as $5 \%$ (Brand 1984). The photosynthetic rate of diatoms including $S$. costatum was inhibited with decreased salinity in continuous cultures in the range from 24 to $8 \%$ (Rijstenbil \& Sinke 1989). However, a gradual increase in salinity enhanced the rate (Miller \& Kamykowski 1986, Rijstenbil \& Sinke 1989). Thus, the inevitable restoration of salinity in diluted waters in Tokyo Bay after rainfall may have provided a similar enhancement, leading to a subsequent bloom.

The present study confirmed the importance of Skeletonema costatum in the inner bay, contributing about $19 \%$ of total annual primary production. However, volume-specific SSP, as growth potential, was lower than other dominant species in the assemblage such as Heterosigma akashiwo. This relatively low growth potential of $S$. costatum was difficult to reconcile with the successful establishment of this species in Tokyo Bay (Marumo \& Murano 1973, Marumo et al. 1974). Compared to H. akashiwo, chlorophyll a per unit cell volume in $S$. costatum was about 5- to 19-fold less and its C:chl a ratios were also lower (Table 2). This may explain why the SSP of $S$. costatum was lower than for $H$. akashiwo, but does not explain the abundance of $S$. costatum in the bay. There are 3 possible explanations: (1) $S$. costatum somehow attains high photosynthetic capacity during the initial phase of its blooms, (2) the asexual mode of vegetative cell enlargement of $S$. costatum may have provided a competitive advantage, and (3) there exists selective grazing pressure favoring the proliferation of S. costatum.

The first explanation is based on the distinctive fluctuations of volume-specific SSP of Skeletonema costatum which may enable it to surpass the growth of co-occurring species. Although we failed to find the factors responsible for the high volume-specific SSP (Fig. 7), temporal changes of environmental factor(s), as discussed for salinity above, may have induced enhancement of growth activity. At the initiation of $S$. costatum blooms its growth rate can be elevated to a one order higher magnitude than that in the peak period of blooms (Fig. 6), and may exceed the rates of co-occurring species (Table 1), which also must fluctuate. This capability for rapid growth of short duration likely brings about blooms of $S$. costatum. Furthermore, this species comprised a substantial proportion of the phytoplankton assemblage even during non-bloom periods from spring through early autumn (Fig. 3), and the development of blooms based on the potentiality for rapid growth may have been supported by the abundance of nutrients which never become limiting (Fig. 7). The enhancement of growth activity probably occurs patchily on rather small temporal and spatial scales and was hard to detect with the method used in the present study.

Asexual cell enlargement of vegetative cells would be of ecological advantage if the environments lacked necessary stimuli for auxosporulation (Gallagher 1983). Indeed, there is evidence that this may be the case. The cell size of Skeletonema costatum fluctuates considerably throughout the year (Fig. 5). Gallagher (1983) reported that the asexual mode of vegetative cell enlargement (11.9 to $13.7 \mu \mathrm{m}$ in diameter) was more common than auxosporulation in $S$. costatum clones isolated from Narragansett Bay and New York Bight (USA). In summer, $S$. costatum larger than $15 \mu \mathrm{m}$ were exceedingly rare in the inner bay even during blooms (Han unpubl.). The cell sizes in the bay were certainly comparable to enlarged vegetative cells, but 
smaller than auxospores produced by the clones isolated from Nagasaki Bay and Narragansett Bay (Migita 1969, Gallagher 1983). In Tokyo Bay, large cells (about 17 to $22.5 \mu \mathrm{m}$ ) were more frequently encountered in winter than during summer. It seemed, therefore, that the enlargement of $S$. costatum during summer was primarily due to asexual processes.

There is insufficient information to evaluate whether selective grazing has any effect on the proliferation of Skeletonema costatum populations in the bay.

Volume-specific SSP values of natural populations of Skeletonema costatum in our study fluctuated little throughout the year (Fig. 5). This is inconsistent with the findings of Gallagher (1982) who found that a natural population of $S$. costatum was composed of strains with different growth characteristics, and that summer populations had higher growth rates than did winter populations. Good correlations between cell numbers and carbon uptake of isolated cells from a given assemblage throughout the year in the present study (Fig. 2) strongly demonstrated a small degree of intra-specific variations of SSP in S, costatum, indicating that clonal variation in natural populations of this species was not pronounced in Tokyo Bay.

Acknowledgements. We thank Drs G.-Y. Rhee, G.-H. Hong and anonymous referees for critical comments and suggestions, and Dr M. Terazaki for cooperation in the radioisotope experiments.

\section{LITERATURE CITED}

Boulding, E. G., Platt, T. (1986). Variation in photosynthetic rates among individual cells of a marine dinoflagellate. Mar. Ecol. Prog. Ser. 114: 589-598

Braarud, T., Hofogsvang, F., Hjelmfoss, P., Overland, A.-K. (1974). The natural history of the Hardanger fjord. Sarsia 55: 63-98

Brand, L. E. (1984). The salinity tolerance of forty-six marine phytoplankton isolates. Estuar. coast. Shelf. Sci. 18: $543-556$

Carpenter, E. J., Chang, J. (1988). Species-specific phytoplankton method. Mar. Ecol. Prog. Ser. 43: 105-111

Curl, H. Jr, McLeod, G. C. (1961). The physiological ecology of a marine diatom, Skeletonema costatum (Grev.) Cleve. J. mar. Res. 19: 79-88

Gallagher, J. C. (1982). Physiological variation and electrophoretic banding patterns of genetically different seasonal populations of Skeletonema costatum (Bacillariophyceae). J. Phycol. 18: 148-162

Gallagher, J. C. (1983). Cell enlargement in Skeletonema costatum (Bacillariophyceae). J. Phycol. 19: 539-542

Han, M.-S. (1988). Studies on the population dynamics and photosynthesis of phytoplankton in Tokyo Bay. Ph.D. thesis, University of Tokyo

Han, M.-S., Furuya, K., Nemoto, T. (1989). Species-specific photosynthesis of red tide plankton in Tokyo Bay. In: Okaichi, T., Anderson, D. W., Nemoto, T. (eds.) Red tides: biology, environmental science and toxicology. Elsevier, New York, p. 211-214

Hitchcock, G. L., Smayda, T. J. (1977). Bioassay of lower Narrangansett Bay waters during the 1972-1973 winterspring bloom using the diatom Skeletonema costatum. Limnol. Oceanogr. 22: 132-139

Hogetsu, K. Sakamoto, M., Sumikawa, H. (1959). On the high photosynthetic activity of Skeletonema costatum under the strong light intensity. Bot. Mag., Tokyo 72: 421-422

Kovala, P. E., Larrance, J. D. (1966). Computation of phytoplankton cell numbers, cell volume, cell surface and plasma volume per liter, from microscopical counts. Dept. Oceanogr., Univ. Washington, Spec. Rep. 38: 1-91

Marumo, R., Murano, M. (1973). Succession of plankton diatoms in Tokyo Bay. La Mer 11: 70-82

Marumo, R., Sano, A., Murano, M. (1974). Further study on succession of plankton diatoms in Tokyo Bay. La Mer 12: $145-156$

Migita, S. (1967). Sexual reproduction of centric diatom Skeletonema costatum. Bull. Jap. Soc. scient. Fish. 19: 79-88

Miller, R. L., Kamykowski, D. L. (1986). Short-term photosynthetic responses in the diatom Nitzschia americana to a simulated salinity environment. J. Plankton Res. 8: 305-315

Nishizima, T., Hata, Y. (1986). Physiological ecology of Skeletonema costatum (Greville) Cleve and Eutreptiella sp. on B group vitamin requirements. Bull. Jap. Soc. scient Fish. 52: 173-179

Parsons, T. R., Maita, Y., Lalli, C. M. (1984). A manual of chemical and biological methods for seawater analysis. Pergamon Press, Oxford

Rijstenbil, J. W., Sinke, J. J. (1989). The influence of salinity fluctuation on the ammonium metabolism of the marine diatom Skeletonema costatum grown in continuous culture under continuous illumination. In: Rijstenbil, J. W. (ed.) Growth and nitrogen metabolism of marine diatoms in brackish water in response to salinity fluctuation. Delta Institute for Hydrobiological Research, Texel, Netherlands, communication no. 419: p 79-103

Rivkin, R. B., Seliger, H. H. (1981). Liquid scintillation counting for $\mathrm{C}$ uptake of single algal cells isolated from natural samples. Limnol. Oceanogr. 26: 780-785

Rivkin, R. B., Voytek, M. A., Seliger, H. H. (1982). Phytoplankton division rates in light-limited environments: two adaptations. Science 215: 1123-1125

Sakshaug, E., Andresen, K. (1986). Effect of light regime upon growth rate and chemical composition of a clone of Skeletonema costatum from the Trondheimsfjord, Norway. J, Plankton Res. 8: 619-637

Sato, N., Furuhashi, K., Ebara, S. (1981). Extraction method for phytoplankton pigments without grinding for fluorometric measurement employed by Japan Meterological Agency. Bull. Plankton Soc. Japan 28: 411-418 (in Japanese)

Smayda, T. J. (1973). The growth of Skeletonema costatum during a winter-spring blooming in Narragansett Bay, Rhode Island. Norw. J. Bot. 20: 210-247

Strathmann, R. R. (1967). Estimating the organic carbon content of phytoplankton from cell volume of plasma volume. Limnol. Oceanogr, 12: 411-418 